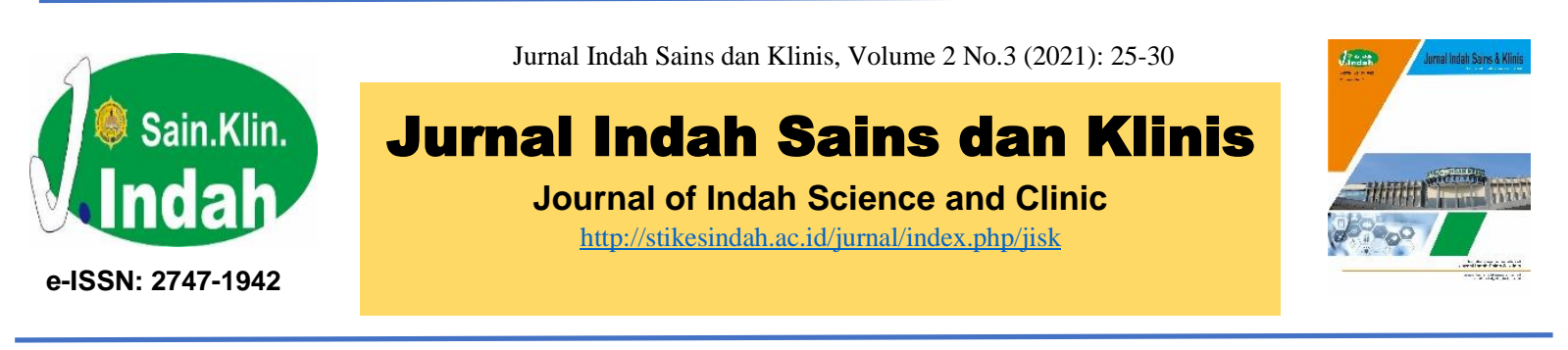

\title{
Study Antropometri Indeks Nasalis Suku Jawa, Batak Dan Melayu Pada Mahasiswa FK UISU Kota Medan 2021
}

\author{
Wan Muhammad Ismail ${ }^{1}$ \\ ${ }^{1}$ Departemen Anatomi FK UISU Sisingamangaraja 2A Medan \\ *Corresponding author: dr.eenk835@gmail.com
}

Received: 24 Oktober 2021; Revised: 29 Nopember 2021; Accepted: 1 Desember 2021

DOI: $10.52622 /$ jisk.v2i3.36

\begin{abstract}
Facial anthropometry is known as the science of measuring and analyzing the proportions of the human face and provides important information about differences in shape and size of various races, ages, and sexes. The size, shape and position of the nose determine the aesthetic appearance of the face and are important in prognosis. care, references to diagnostic, clinical, and forensic procedures. The general objective of this study was to obtain data on various forms of nasal indices in Javanese, Batak, Malay ethnic groups. This research is a descriptive study with a cross sectional approach. Data collection uses primary data by measuring. Samples were taken using purposive sampling method. The research sample is 75 people, each ethnic group is 25 people. Based on the nasalis lepthorhine index, the highest percentage was in the Javanese, $60 \%$ Mesorhine, the highest was the Malay, $41.4 \%$, and the platyrrhine category was the largest, the Javanese and Batak, 34.3\%, respectively, hyperchamarine, 33.3\%, respectively, in the Javanese, Malay and Batak. Variations in the nasalis index prove that there is a possible gene pool that provides variation in the population. The gene pool of a particular population can change over time through the process of evolution. This can occur due to a variety of mechanisms, including mutation, natural selection, and genetic drift.
\end{abstract}

Keyword : Nasalis index, ethnic group, medical student of FK UISU

\begin{abstract}
ABSTRAK
Antropometri wajah dikenal sebagai ilmu mengenai pengukuran dan analisis proporsi wajah manusia dan memberikan informasi penting tentang perbedaan dalam bentuk dan ukuran berbagai ras, usia, dan jenis kelamin. Ukuran, bentuk dan posisi hidung menentukan penampilan wajah yang estetis dan penting dalam prognosis perawatan, referensi untuk prosedur diagnostik, klinis, dan forensik. Tujuan umum dari penelitian ini adalah untuk memperoleh data tentang berbagai bentuk indeks nasalis pada suku Jawa, Batak, Melayu. Penelitian ini merupakan penelitian deskriptif dengan pendekatan cross sectional. Pengumpulan data menggunakan data primer dengan melakukan pengukuran. Sampel diambil dengan menggunakan metode purposive sampling. Sample penelitian berjumlah 75 orang masing-masing suku 25 orang. Berdasarkan Indeks nasalis lepthorhine paling besar pada suku jawa 60 $\%$ mesorhine paling besar suku melayu $41,4 \%$ dan kategori platyrrhine paling besar suku jawa dan batak masing-masing 34,3\%, hyperchamarine masing-masing 33,3\% pada suku jawa melayu dan batak. Variasi indeks nasalis membuktikan bahwa adanya kemungkinan gene pool yang memberikan
\end{abstract}


variasi pada populasi masyarakat. Kumpulan gen populasi tertentu dapat berubah dari waktu ke waktu melalui proses evolusi. Hal ini dapat terjadi karena berbagai macam mekanisme, termasuk diantaranya mutasi, seleksi alam, dan pergeseran genetic.

Kata Kunci: Indeks nasalis, suku, mahasiswa FK UISU

\section{PENDAHULUAN}

Antropometri merupakan gabungan seni dan ilmu sains mengenai teknik sistematis untuk mengukur, mengamati, dan menetapkan geometri fisik dan proporsi tubuh manusia $(1,2,3)$. Antropometri manusia bervariasi tergantung berbagai faktor. Variasi antropometri dapat disebabkan oleh usia, jenis kelamin, ras dan suku bangsa, serta pekerjaan (4). Berbagai penelitian telah dilakukan untuk membuktikan hal ini, baik pada usia, jenis kelamin, pekerjaan dan suku bangsa $(4,5)$. Variabilitas dimensi tubuh manusia dipengaruhi oleh beberapa faktor antara lain: umur, jenis kelamin, ras/etnik, jenis pekerjaan/profesi, geografi dan status sosial dan nutrisi (6). Antropometri wajah dikenal sebagai ilmu mengenai pengukuran dan analisis proporsi wajah manusia dan memberikan informasi penting tentang perbedaan dalam bentuk dan ukuran berbagai ras, usia, dan jenis kelamin $(3,7,8)$. Salah satu ciri tubuh manusia yang umum adalah struktur wajah manusia, yaitu sepasang mata dan telinga, satu mulut dan hidung. Semua ini tersusun teratur secara bilateral simetri. Persamaan dalam struktur ini memungkinkan pemanfaatannya di bidang antropometri (8).

Hidung merupakan bagian estetika yang paling menonjol dari profil wajah, karena hidung terproyeksi paling anterior secara tampak lateral. Pada penampakan frontal, posisi hidung terletak di garis tengah, maka bila terdapat asimetri hidung akan teridentifikasi dengan mudah. Hidung merupakan bagian estetika tersering yang diubah oleh para ahli bedah plastik dan rekonstruksi, oleh karena itu hidung banyak dipelajari untuk menentukan proporsional estetika dan hubungannya dengan bagian wajah lainnya $(9,10,11)$. Ukuran, bentuk dan posisi hidung menentukan penampilan wajah yang estetis dan penting dalam prognosis perawatan (12). Data-data hasil penelitian mengenai hidung terkait jenis kelamin, usia dan ras, menyediakan informasi referensi untuk prosedur diagnostik, klinis, dan forensik (penuaan baik pada orang yang hidup maupun yang mati, identifikasi pribadi, rekonstruksi wajah) (13).

Indeks hidung adalah rasio antara lebar hidung dan panjang hidung dikalikan 100. Indeks ini menggambarkan bentuk hidung. Indeks hidung dapat digunakan untuk membantumenentukan identitas pribadi, terutama ras, perbedaan etnis dan gender (14). Pembagian bentuk hidung menurut antropologi menjadi 3 golongan besar, yaitu golongan Kaukasia (lepthorrhine), Asia (mesorrhine) dan Afrika (platyrrhine). Perbedaan utama antara hidung Kaukasia dan non Kaukasia meliputi ketebalan kulit dan jaringan lunak, kekuatan dan ketebalan kartilago, tinggi dan panjang os nasal, serta bentuk dan orientasi lubang hidung. Secara umum, orang Afrika memiliki perbedaan paling nyata dibandingkan orang Kaukasia, sedangkan orang Asia memiliki karakteristik fisik di antara keduanya $(15,16,17,18)$.

Kekhasan hidung Asia adalah dorsum yang lebar dan rendah, defisiensi proyeksi tip, lobul lebar, kulit lobul tebal, jaringan lemak subkutis dan retraksi kolumela. Hidung bangsa non Kaukasia mempunyai variasi anatomi tersendiri. Pasien non Kaukasia ini terdiri dari berbagai latar belakang etnik dan morfologi (15). Studi di luar Indonesia oleh Sebuah Studi antropometri dari beberapa Dasar Parameter Hidung Tiga Etnis Utama Grup di Negara Bagian Kogi, Nigeria, mengakuisisi tiga suku di Negara Bagian Kogi, Nigeria memiliki jenis hidung platyrrhine (19).

Penelitian mengenai nasal indeks dalam negri Indonesia pada subras Deutro Melayu lainnya yaitu pada suku Bugis, penelitian yang pernah dilakukan di Sulawesi Selatan dan Barat nasal indeks laki-laki 90,05 dan perempuan 85,19 yang tergolong pada kategori hidung Platyrrhine (20). Indeks hidung masyarakat minang kabau disurabaya baik perempuan maupun laki-laki paling besar terletak pada kategori $2(70,0-$ $84,9)$ yaitu pada sampel laki-laki sebesar $65,7 \%$, pada sampel perempuan sebesar 50,0 \% dan tergolong ke dalam hidung dengan kategori sedang (mesorrhine) (21).

Berdasarkan Badan Pusat Statistik Provinsi Sumatera Utara tahun 2016, kota Medan memiliki 21 kecamatan dengan jumlah penduduk yang mencapai 2,229,408 jiwa (22). Suku di Kota Medan terdiri dari berbagai etnik, dimana suku Jawa yang menetap di Medan menduduki peringkat pertama, yaitu sebesar 34\%. Suku Batak menjadi suku kedua terbesar yang mendiami Medan, yaitu sebesar $21 \%$. 
Kota Medan identik dengan suku Batak karena suku asli yang dulu mendirikan Kota Medan merupakan suku Batak Karo $(22,23)$.

Berdasarkan latar belakang peneliti ingin menggambarkan indeks nasalis pada suku Jawa, Batak dan Melayu pada mahasiswa FK UISU Tahun 2021 di kota Medan

\section{METODE PENELITIAN}

Metode penelitian ini berjenis penelitian deskriptif dengan pendekatan cross sectional. Waktu penelitian dilaksanakan Penelitian dimulai bulan Oktober-Nopember 2021. Tempat penelitian dilaksanakan Fakultas Kedokteran Jl. STM 77 Kel. Suka Maju Kec. Medan Johor Kota Medan dan Sisingamangaraja 2A Medan Kota. Populasi penelitian ini adalah seluruh populasi berdasarkan kriteria inklusi yang dibuat

a. Kriteria inklusi dari penelitian ini:

a. Mahasiswa aktif di FK UISU Tahun 2021 angkatan 2018, 2019, 2020

b. Mahasiswa suku Jawa, Batak dan Melayu pada Mahasiswa FK UISU Tahun 2021

c. Memiliki dua turunan yang sama (Riwayat keluarga yaitu bapak-ibu dan kakeknenek dari bapak / ibu memiliki suku yang sama)

c. Kriteria eksklusi dari penelitian ini:

a. Memiliki riwayat trauma pada bagian hidung

b. Memiliki kelainan kongenital hidung luar

c. Memiliki penyakit- penyakit di hidung bagian luar

d. Memiliki Riwayat operasi pada bagian hidung luar

Pengambilan sample penelitian ini menggunakan purposive sampling sehingga sampel adalah semua subyek yang datang berurutan dan memenuhi kriteria pemilihan dimasukkan dalam penelitian sampai jumlah subyek yang diperlukan terpenuhi sebanyak 75 orang. Masing-masing suku berjumlah 25 orang

Pada penelitian ini instrumen penelitian yang digunakan adalah Instrumen dalam penelitian ini adalah lembar informed consent, lembar kuesioner untuk menyesuaikan identitas responden dengan kriteria penelitian. Pada lembar tersebut terdapat pula kolom pencatatan hasil pengukuran,Hitungan indeks nasalis dan kategori bentuk hidung. Alat tulis untuk mencatat hasil pengukuran dan kaliper digital, camera digital,

Analisis data dilakukan dengan analisis data univariat untuk distribusi frekuensi setiap variabel sehingga mendeskripsikan seluruh variabel yang digunakan untuk melihat penyebarannya, kemudian dilakukan pengelompokkan setiap variabel.

Indeks Nasalis = Lebar Hidung(al-al)x100/Panjang hidung(n-ns)

Klasifikasi tipe bentuk hidung menurut (Matory et al., 1985).

-Lepthorine (kaukasian), 55,0-69,9= hidung sempit

-Mesorrhine, 70,0-84,9 =hidung sedang

-Platyrrhine (Asia), 85,0-99,9= hidung lebar

-Hyperchamaerhhine (kulit hitam) lebih besar dari 100= hidung sangat lebar

\section{HASIL DAN PEMBAHASAN}

Distribusi Frekuensi Suku Jawa,Batak Dan Melayu Pada Mahasiswa FK UISU Tahun 2021 berdasarkan Usia 
Tabel 1 Usia Responden

\begin{tabular}{r|lll}
\multicolumn{1}{c}{ No } & Usia(tahun) & Frekuensi & Presentase \\
\hline \multirow{2}{*}{2} & $18-20$ & 41 & 54.7 \\
2 & $21-23$ & 34 & 45.3 \\
& Toutal & 75 & 100
\end{tabular}

Berdasarkan tabel 1 distribusi frekuensi usia pada suku jawa batak dan melayu usia 18-20 tahun berjumlah 41 orang dengan $54,7 \%$ dan usia $21-23$ tahun berjumlah 34 orang dengan 45,3\%

Distribusi Frekuensi Suku Jawa,Batak Dan Melayu Pada Mahasiswa FK UISU Tahun 2021 berdasarkan Jenis Kelamin

Tabel 2 Jenis Kelamin

\begin{tabular}{l|lll}
\multicolumn{2}{l}{$\begin{array}{l}\text { Jenis } \\
\text { kelamin }\end{array}$} & Frekuensi & Presentase \\
\hline 1 & Perempuan & 47 & 62.7 \\
2 & Laki-laki & 28 & 37.3 \\
& Total & 75 & 100
\end{tabular}

Berdasarkan tabel 2 distribusi frekuensi jenis kelamin pada suku jawa batak dan melayu perempuan berjumlah 47 orang dengan $62,7 \%$ dan pada laki-laki berjumlah 28 orang dengan $37,3 \%$

\section{Distribusi frekuensi Indeks Nasalis suku Jawa melayu Batak}

\section{Tabel 3 Indeks Nasalis}

\begin{tabular}{|c|c|c|c|c|c|c|c|}
\hline \multirow[t]{3}{*}{ NO } & \multirow[t]{3}{*}{ Kategori Nasal } & \multicolumn{6}{|c|}{ Suku } \\
\hline & & \multicolumn{2}{|c|}{ Jawa } & \multicolumn{2}{|c|}{ Melayu } & \multicolumn{2}{|c|}{ Batak } \\
\hline & & frek & $\%$ & frek & $\%$ & Frek & $\%$ \\
\hline 1 & Leptorhine & 3 & 60 & 0 & 0 & 2 & 40 \\
\hline 2 & Mesorhine & 8 & 27,6 & 12 & 41,4 & 9 & 31 \\
\hline 3 & Platyrhine & 12 & 34,3 & 11 & 31,4 & 12 & 34,3 \\
\hline 4 & Hyperchamarhine & 2 & 33,3 & 2 & 33,3 & 2 & 33,3 \\
\hline & Total & 25 & 100 & 25 & 100 & 25 & 100 \\
\hline
\end{tabular}

Berdasarkan table 3 kategori indeks nasalis lepthorhine paling banyak pada suku jawa $60 \%$ mesorhine paling banyak suku melayu $41,4 \%$ dan kategori platyrrhine paling besar suku jawa dan batak masingmasing $34,3 \%$, hyperchamarine masing-masing 33,3 \% pada suku Jawa melayu batak

\section{Rerata indeks nasalis suku Jawa Batak Melayu}

Tabel 4 Rerata dan standart deviasi indek nasalis

\begin{tabular}{l|lll} 
No & Suku & $\begin{array}{l}\text { Rerata Indeks } \\
\text { Nasalis }\end{array}$ & Standart Deviasi \\
\hline $\mathbf{1}$ & Jawa & 86,016 & 13,1351 \\
$\mathbf{2}$ & Melayu & 84,460 & 12,5691 \\
$\mathbf{3}$ & Batak & 81,460 & 17,7407
\end{tabular}


Rerata indeks nasalis Jawa 86,016 bentuk hidung platyrrhine hidung lebar, rerata indeks nasalis suku Melayu 84,43 bentuk hidung mesorhine hidung sedang, rerata indeks nasalis suku Batak 81,46 bentuk hidung mesorhine hidung sedang

Penelitian ini indeks nasalis lepthorhine bentuk hidung sempit paling banyak pada suku jawa 60 $\%$ berbeda dengan penelitian perempuan jawa diJakarta didapatkan pada wanita Jawa 90\% dari Wanita Jawa memiliki hidung yang lebih lebar daripada jarak intercantal (24).

Namun Penelitian sejalan juga dilakukan di Universitas Al-Rafidain di Baghdad tahun 2020 tentang indeks nasal dengan menggunakan sebanyak 311 mahasiswa jurusan farmasi dengan membandingkan dua etnis yaitu pada etnis Arab menunjukkan nilai indeks $(60,0)$ dan pada etnis Kurdi $(60,6)$. Kedua nilai indeks yang didapat mengacu kepada bentuk hidung leptorrhine. Hal ini menunjukkan bahwa etnis Arab dan Kurdi yang tergolong ras Kaukasoid memiliki bentuk hidung leptorrhine (25).

Mesorhine bentuk hidung sedang paling banyak suku melayu 41,4\% sesuai dengan penelitian serupa juga ditemukan pada penelitian tahun 2013 bahwa hidung suku bangsa Minangkabau termasuk ke dalam kategori mesorrhine dan platyrhine. Sesuai juga dengan penelitian diDenpasar pada suku minangkabau Mesorrhine dan Platyrrhine banyak temuan data laki-laki maupun perempuan memiliki indeks hidung laki-laki sebesar 65,7\% dan pada temuan data perempuan sebesar 50,0 \% (21).

Kategori platyrrhine bentuk hidung lebar dijumpai pada suku jawa dan batak masing-masing 34,3 $\%$ sama dengan penelitian ukuran bentuk hidung suku batak diSumatera Utara dijumpai indeks nasal batak platyrhine sekitar 92, 33 dan sejalan juga dengan penelitian tahun 2020 pada 192 orang dari 3 etnis yaitu etnis Chinese-Indonesia, Batak dan Sunda, terdapat 64 orang per grup dengan 32 orang lakilaki dan 32 orang perempuan. Hasil penelitian menunjukkan nilai rata-rata indeks nasal pada laki-laki $(85,51)$ dan perempuan etnis Batak $(85,49)$ dengan bentuk hidung platyrrhine (27). Kategori hyperchamarine masing-masing hanya dididapat $33,3 \%$ pada suku Jawa dan melayu

\section{KESIMPULAN}

Variasi indeks nasalis ini membuktikan bahwa adanya kemungkinan gene pool yang memberikan variasi pada populasi masyarakat. Kumpulan gen populasi tertentu dapat berubah dari waktu ke waktu melalui proses evolusi. Hal ini dapat terjadi karena berbagai macam mekanisme, termasuk diantaranya mutasi, seleksi alam, dan pergeseran genetik.

Kemungkinan lain pernikahan masyarakat perantau suku bangsa dengan bangsa lain menjadi factor penentu keanekaragaman bentuk hidung

\section{DAFTAR PUSTAKA}

1. Sivaraj A. Essentials of orthodontics. New Delhi: Jaypee Brothers Medical Publisher, 2013: $11-6,59,79-81,171-7,218-25,425-7,448-57$

2. Karad A. Clinical orthodontics current concepts, goals, mechanics. 2nd Edition. New Delhi: Elsevier: 13-9,51,112-7,182-8.

3. Alvi FB, Pears R, Kasabov N. An evolving spatio-temporal approach for gender and age group classsification with spiking neural networks. Evolving Systems 2017; 9(2): 145-56.

4. Mehrparvar, A. H., Mirmohammadi, S. J., Hafezi, R., Mostaghaci, M., dan Davari, M. H. 2015. Static anthropometric dimensions in a population of Iranian high school students: considering ethnic differences. Human factors, Vol. 57(3):447-460

5. Wickens, C. D., Lee, J. D., Liu, Y., Becker, S. E. G. 2004. An Introduction to Human Factors Engineering, 2nd ed., New Jersey: Prentice Hall.

6. Purnomo H 2013, antropometri dan aplikasinya Yogyakarta cetakan I Graha Ilmu

7. Islam M, Alam MK. A 3D study of facial skeleton morphometry using CT Scan: An Overview. Int Med J 2017; 24(4): 326-9. 
8. 38. Kainz O, Michalko M, Jakab F. On the extraction of anthropometric parameters by visual and non-visual means. EAI Endorsed Transactions on Pervasive Health and Technology 2017; 3(12): $1-6$

9. Wall BM. 1998. Facial Analysis. In : Bailey, B.J. Head and Neck SurgeryOtolaryngology 2nd ed. Philadelphia. Lippinccott-Raven : pp. 2531- 44.

10. Becker DG. 2003. Rhinoplasty. Journal of Long-Term of Medical Implants, 13(3) : pp. 223-46. Becker DG, Toriami DM. 2008. Rhinoplasty analysis. Available from URL : http://www.therhinoplastycenter.com/RhinoplastyManual/ch2_1.html

11. Finn JC. 2005. Rhinoplasty, Broad Nasal Tip. Available from URL : www.emedicine.com/ent/topic111.htm.

12. Singh G, ed. Textbook of orthodontics. 2nd Edition. New Delhi: Jaypee Brothers Medical Publishers, 2007: 3,68,123-30

13. Sforza C, Grandi G, de Menezes M, Tartaglia GM, Ferrario VF. Age and sex related changes in the normal human external nose. Forensic Sci International 2010; 204: 205.e1-205e9.

14. Rajakshmi CH, Singh MS, Devi HB. Chandramanisingh L. Cephalic index of foetues of Manipuri population - A baseline study. J Anat Soc India 2001;50:8 $\square 10$.

15. Matory Jr WE, Falces E. 1986. Non-Caucasian Rhinoplasty : A 16-Year Experience. Plasctic and Reconstructive Surgery : pp. 239-51.

16. Milgrim LM, Lawson W, Cohen AF. 1996. Anthropometric Analysis of the Female Latino Nose. Revised Aesthetic Concepts and Their Surgical Implications. Arch Otolaryngol Head Neck Surg/Vol 122, Oct : pp. 1079-86.

17. Stevens R, Calhoun K, Quinn FB. 1997. Facial Analysis. Dept of Otolaryngology, UTMB, Galveston. Available from URL : http://utmb.edu/otoref/grnds/facial2.html.

18. Hodgkinson DJ. 2007. The Eurasian Nose : Aesthetic Principles and Techniques for Augmentation of the Asian Nose with Autogenous Grafting. Journal of Aesthetic Plastic Surgery. Vol. 31 : pp. 28-31.

19. Oluwayinka Paul, et all. 2015. An Anthropometric Study of some Basic Nasal Parameters of Three Major Ethnic Groups in Kogi State, Nigeria. American Journal of Clinical and Experimental Medicine 2015; 3(2): $62 \square 7$

20. Rahmawati, Julianita et al. 2006. Analisis Fotometrik Wajah Suku-Suku di Sulawesi Selatan dan Sulawesi Barat (Studi Anthropometrik Sub Ras Deutro Melayu dan Proto Melayu) Dibawakan pada 1st ENT Head And Neck Conference Jakarta, Desember.

21. Sari AK 2018 ,Variasi Morfologi Hidung Masyarakat Suku Bangsa Minangkabau Dikota Surabaya JawaTimur J.Antropologi UNAIR

22. Muhardiansyah Y. Jangan salah, warga Medan tak selalu identik dengan orang Batak. Merdeka. 2015 Sep 19; 1.

23. Badan Pusat Statistik Provinsi Sumatera Utara. Jumlah penduduk menurut jens kelamin, rasio jenis kelamin dan kabupaten/kota 2016. 92 April 2018. https://sumut.bps.go.id/frontend/linkTabelStatis/view/id/577. (13 November 2018). 52.

24. Erlangga, Mirta HR. 'Antropometri dan Analisis Wajah dengan Menggunakan Rhinobase Software pada Perempuan Jawa Murni di Jakarta, Tesis, Universitas Indonesia. 2006. pp. 1-91

25. Farhan SS, Al-Jewari WM, Afar AQ, et al. Anthropometric Study of Nose Parameters in Iraqi Arabic and Kurdish Subjects. Indian Journal of Forensic Medicine \& Toxicology 2020; 14(2): 2027-33.

26. Mulyana B, 2007, 'Ukuran dan BentukHidung Pada Suku Batak', Tesis, Universitas Sumatera Utara, pp. 1-61

27. Karolina A, Rusman AA, Syukriani Y. The Similarity Between ChineseIndonesian, Sundanese and Bataknese Based on Facial and Nasal Index. Ejki 2020; 8(2): 81-7. 